\title{
Preliminary Survey for Setting Evaluation Standards of Wood Pellet Safety ${ }^{1}$ (גip
}

\author{
In Yang ${ }^{2} \cdot$ Sung-Mo Kang ${ }^{3} \cdot$ Young Hun $\mathrm{Kim}^{3} \cdot$ Gyu-Seong Han $\mathbb{D}^{4, \dagger}$
}

\begin{abstract}
As the use of wood pellets increases, there is an increasing interest in the safety of the wood pellets themselves to avoid physical and chemical damage to people and the environment. This study investigated the contents of nitrogen, sulfur, chlorine, arsenic, cadmium, chromium, copper, lead, mercury, nickel, zinc, and cesium in wood pellets distributed in Korea as a preliminary survey for establishing safety evaluation standards for wood pellets. Nitrogen, sulfur, chlorine, and heavy metal contents of wood pellets produced in Korea met the specification for the 1st grade of wood pellets determined by the National Institute of Forest Science and the specification for the commercial and residential wood pellets of A1 grade determined by the ISO and the evaluation standards for wood pellet safety determined by the Korean Forest Service. However, among imported wood pellets, some wood pellets contained nitrogen, sulfur, chlorine, and heavy metal exceeding the safety evaluation standards. Cesium radioactivity was not detected in domestic wood pellets. Cesium radioactivity was detected from wood pellets imported from Japan, but it was below the limits specified in the wood pellet safety evaluation standards. In conclusion, by establishing safety standards for wood pellets, we believe that safe wood pellets will be used.
\end{abstract}

Keywords: wood pellet, safety, nitrogen, sulfur, chlorine, heavy metal, cesium radioactivity

\section{INTRODUCTION}

Since the start of the wood pellet production in 2009, South Korea has seen its market continuously growing, including the completion of a factory in 2017 that can produce 300K-ton wood pellets per year (KEA, 2017). Meanwhile, the number of imported wood pellets also increased rapidly so that about $1.7 \mathrm{M}$ tons of wood pellets have been imported in 2016 from Vietnam, Malaysia, etc. (FBEA, 2017).
Along with the increasing amount of wood pellet use, the safety issues of wood pellets for producers, users, and environments have been raised by the EU (AEBIOM, 2013). Since 2010, there have been reports on hazardous gases, fires, and explosions during the use or production of wood pellets in the EU. Human and environmental risks caused by carbon monoxide, nitrogen oxide, sulfur oxide, hydrocarbons, fine dust, volatile organic compounds, polycyclic aromatic hydrocarbons and other hazards generated during the

${ }^{1}$ Date Received July 11, 2018, Date Accepted September 8, 2018

2 SCION. Te Papa Tipu Innovation Park, 49 Sala Street, Private Bag 3020, Rotorua, 3046, New Zealand

${ }^{3}$ Korea Forestry Promotion Institute, Seoul, 07570, Republic of Korea

${ }^{4}$ Department of Wood and Paper Science, College of Agriculture, Life \& Environments Sciences, Chungbuk National University, Cheongju 28644, Republic of Korea

† Corresponding author: Gyu-Seong Han (e-mail: wood@chungbuk.ac.kr, ORCID: 0000-0003-3835-2063) 
Table 1. Safety evaluation standard for wood pellet (KFS, 2017)

\begin{tabular}{|c|c|c|}
\hline $\begin{array}{l}\text { Types of hazardous } \\
\text { substances }\end{array}$ & Allowable release or content & Testing method \\
\hline $\begin{array}{l}\text { Cesium radiation } \\
\text { (Cs-137 \& Cs-134) }\end{array}$ & $30 \mathrm{~Bq} / \mathrm{kg}$ or less & $\begin{array}{l}\text { Measurement of radioactivity in the environment - } \\
\text { Soil - Part 3: Measurement of gamma-emitting } \\
\text { radionuclides (KS A ISO 18589-3) }\end{array}$ \\
\hline Sulfur (S) & $0.05 \%$ or less & \multirow{11}{*}{$\begin{array}{l}\text { Standard and Quality Criteria of Wood-based } \\
\text { Products } \\
\text { (National Institute of Forest Science) }\end{array}$} \\
\hline Chlorine $\mathrm{Cl}$ ) & $0.05 \%$ or less & \\
\hline Nitrogen (N) & $1.0 \%$ or less & \\
\hline Arsenic (As) & $1.0 \mathrm{mg} / \mathrm{kg}$ or less & \\
\hline Cadmium (Cd) & $0.5 \mathrm{mg} / \mathrm{kg}$ or less & \\
\hline Chromium (Cr) & $10 \mathrm{mg} / \mathrm{kg}$ or less & \\
\hline Copper (Cu) & $10 \mathrm{mg} / \mathrm{kg}$ or less & \\
\hline Lead $(\mathrm{Pb})$ & $10 \mathrm{mg} / \mathrm{kg}$ or less & \\
\hline Mercury (Hg) & $0.05 \mathrm{mg} / \mathrm{kg}$ or less & \\
\hline Nickel (Ni) & $10 \mathrm{mg} / \mathrm{kg}$ or less & \\
\hline Zinc (Zn) & $100 \mathrm{mg} / \mathrm{kg}$ or less & \\
\hline
\end{tabular}

combustion of wood pellets have also been raised. Therefore, an international summit on the safety of wood pellets was first held in Fugen, Austria, in March 2013, where such problems and measures were discussed.

The "Act on the Sustainable Use of Wood" (KFS, 2018), established in May 2012, stipulates that when wood products are produced and sold, safety evaluations of these products shall be performed so that they would not cause physical and chemical damage to humans and environments. Based on the act, the "Wood Products Safety Evaluation Standards” (KFS, 2017) was announced in December 2014 (Table 1). For wood pellets, the standards stipulate that the permissible amount of cesium radioactivity, sulfur, chlorine, nitrogen, arsenic, cadmium, copper, lead, mercury, nickel, and zinc shall be determined and evaluated accordingly. Research in Korea on wood pellets have focused mainly on the manufacturing characteristics (Lee et al., 2011, Kim et al., 2015, Yang et al., 2017), and only a few studies have reported on the component analysis of wood pellets produced or currently distributed in the market in Korea (Kang et al., 2010,
Nam et al., 2011, Kim et al., 2013).

However, to establish the standards for the safety evaluation of wood pellets, it is necessary to determine the current status of the quality of wood pellet products that are manufactured and distributed in Korea. As a preliminary survey for the public announcement of "Wood Product Safety Evaluation Standards", Korea Forestry Promotion Institute analyzed the characteristics of wood pellets distributed in the Korean market from July to November 2013. Thus, the present study aims to propose the direction toward the revision of the safety evaluation standards by analyzing these results based on the "Wood Product Safety Evaluation Standards" and "Standard and Quality Criteria for Wood Pellets" which were announced later.

\section{MATERIALS and METHODS}

\subsection{Specimens}

Wood pellets of 18 domestic and 33 imported were used as test specimens. These wood pellets were 
collected by the Korea Forest Service between July 2013 and November 2013.

\subsection{Nitrogen, sulfur, chlorine, inorganic substances and radioactivity analysis}

Based on the methods described on the wood pellet quality standards announced by National Institute of Forest Science (NIFOS) (NIFOS, 2017), nitrogen, sulfur, chlorine and inorganic components of wood pellets analyzed by the Korea Forestry Promotion Institute. Nitrogen was analysed with an element analyser, sulphur and chlorine were with ion chromatography, and inorganic substances with an inductively coupled plasma mass analyser.

The radioactivity from wood pellets was determined by measuring the radioactivity content $(\mathrm{Bq} / \mathrm{kg})$ of
Cs-134, Cs-137, and I-131 nuclides using a gamma-ray spectroscope installed with a high-purity germanium detector by Korea Atomic Energy Research Institute based on the HASL-300, Ga-01-R(1997) testing methods. The wood pellet used for the measurement was $500 \mathrm{~g}$ and the duration was 86,000 sec.

\section{RESULTS and DISCUSSION}

\subsection{Nitrogen}

Most well-known hazardous material from nitrogen is nitrogen oxides $\left(\mathrm{NO}_{\mathrm{x}}\right)$, which is known to act as a precursor of ultrafine dust. Nitrogen oxides cause lung diseases, respiratory diseases, weaken immune functions, and the yearly death ratio by nitrogen oxides is estimated to be $2.18-34.5$ per 100,000 people (ME, 2018).

Table 2. Number of companies classified by the nitrogen content of wood pellets

\begin{tabular}{ccccccccc}
\hline (Unit: \%) & $\leqq 0.1$ & $\leqq 0.2$ & $\leqq 0.3$ & $\leqq 0.4$ & $\leqq 0.5$ & $\leqq 0.6$ & $\leqq 0.7$ & $>1.0$ \\
\hline \hline Domestic & 2 & 13 & 3 & & & & \\
Imported & 2 & 12 & 6 & 5 & 6 & 1 & 3 \\
\hline
\end{tabular}

* Maximum $\mathrm{N}$ content for 1st-grade wood pellets standard designated by NIFOS was $\leqq 0.3 \%$.

* Maximum $\mathrm{N}$ content in A1-grade wood pellets standard designated by ISO was $\leqq 0.3 \%$.

Table 3. Specification of graded wood pellets

\begin{tabular}{|c|c|c|c|c|c|c|c|c|c|}
\hline \multirow{3}{*}{ Parameter } & \multirow{3}{*}{ Unit } & \multirow{2}{*}{\multicolumn{2}{|c|}{$\begin{array}{l}\text { Standard and Quality Criteria } \\
\text { of Wood Pellets (NIFOS) }\end{array}$}} & \multicolumn{6}{|c|}{ ISO $17225-2$} \\
\hline & & & & \multicolumn{3}{|c|}{ Residential use } & \multicolumn{3}{|c|}{ Industrial use } \\
\hline & & $1^{\text {st }}$ Grade & $2^{\text {nd }}$ Grade & A1 & A2 & B & I1 & I2 & I3 \\
\hline Sulfur & $\%$ & $\leq 0.05$ & $\leq 0.05$ & $\leq 0.04$ & $\leq 0.05$ & $\leq 0.05$ & $\leq 0.05$ & $\leq 0.05$ & $\leq 0.05$ \\
\hline Chlorine & $\%$ & $\leq 0.05$ & $\leq 0.05$ & $\leq 0.02$ & $\leq 0.02$ & $\leq 0.03$ & $\leq 0.03$ & $\leq 0.05$ & $\leq 0.1$ \\
\hline Nitrogen & $\%$ & $\leq 0.3$ & $\leq 0.5$ & $\leq 0.3$ & $\leq 0.5$ & $\leq 1.0$ & $\leq 0.3$ & $\leq 0.3$ & $\leq 0.6$ \\
\hline Arsenic & $\mathrm{mg} / \mathrm{kg}$ & $\leq 1.0$ & $\leq 1.0$ & $\leq 1.0$ & $\leq 1.0$ & $\leq 1.0$ & $\leq 2.0$ & $\leq 2.0$ & $\leq 2.0$ \\
\hline Cadmium & $\mathrm{mg} / \mathrm{kg}$ & $\leq 0.5$ & $\leq 0.5$ & $\leq 0.5$ & $\leq 0.5$ & $\leq 0.5$ & $\leq 1.0$ & $\leq 1.0$ & $\leq 1.0$ \\
\hline Chromium & $\mathrm{mg} / \mathrm{kg}$ & $\leq 10$ & $\leq 10$ & $\leq 10$ & $\leq 10$ & $\leq 10$ & $\leq 15$ & $\leq 15$ & $\leq 15$ \\
\hline Copper & $\mathrm{mg} / \mathrm{kg}$ & $\leq 10$ & $\leq 10$ & $\leq 10$ & $\leq 10$ & $\leq 10$ & $\leq 20$ & $\leq 20$ & $\leq 20$ \\
\hline Lead & $\mathrm{mg} / \mathrm{kg}$ & $\leq 10$ & $\leq 10$ & $\leq 10$ & $\leq 10$ & $\leq 10$ & $\leq 20$ & $\leq 20$ & $\leq 20$ \\
\hline Mercury & $\mathrm{mg} / \mathrm{kg}$ & $\leq 0.05$ & $\leq 0.05$ & $\leq 0.1$ & $\leq 0.1$ & $\leq 0.1$ & $\leq 0.1$ & $\leq 0.1$ & $\leq 0.1$ \\
\hline Nickel & $\mathrm{mg} / \mathrm{kg}$ & $\leq 10$ & $\leq 10$ & $\leq 10$ & $\leq 10$ & $\leq 10$ & - & - & - \\
\hline Zinc & $\mathrm{mg} / \mathrm{kg}$ & $\leq 100$ & $\leq 100$ & $\leq 100$ & $\leq 100$ & $\leq 100$ & $\leq 200$ & $\leq 200$ & $\leq 200$ \\
\hline
\end{tabular}


Shown in Table 2 are the results of the nitrogen content measurement from wood pellets. The nitrogen content in domestic wood pellets was below the quality standard Grade $1(\leqq 0.3 \%)$ by NIFOS and the non-industry wood pellet quality standard Grade A1 ( $\leqq 0.3 \%$ ) by ISO (NIFOS, 2017; ISO, 2014). However, the nitrogen content in only 20 out of 35 imported wood pellets satisfied the Grade 1 by NIFOS and non-industrial Grade A1 by ISO. When the Grade 4 ( $\leqq 1.0 \%$ ) by NIFOS and non-industrial Grade B by ISO were applied, almost all imported wood pellets, except three products, satisfied the nitrogen content standards.

The Wood Pellet Safety Evaluation Standards stimulate that the allowable nitrogen content is $0.1 \%$ or below. However, the nitrogen content standard for the industrial wood pellet Grade I3 of ISO is set to $0.6 \%$ or below. In Korea, $95 \%$ of the total wood pellet usage is for generation-purpose wood pellets. Therefore, it is necessary to reduce the allowable nitrogen content in the Wood Pellet Safety Evaluation Standards.

\subsection{Sulfur}

Sulfur oxides $\left(\mathrm{SO}_{\mathrm{x}}\right)$, a generic name for compounds of oxygen and sulfur, are often produced as fossil fuels containing sulfur are burned. Sulfur oxides also act as a precursor of ultrafine dust and causes bronchitis, respiratory diseases and asthma, causing 16.6-26.1 deaths per 100,000 people per year (ME, 2018).

Shown in Table 4 are the measurement results of the sulfur content in wood pellets. The sulfur content in domestic wood pellets was shown to be below the Grade 1 of NIFOS ( $\leqq 0.05 \%)$ and non-industrial wood pellet A1 Grade by ISO. However, only 30 out of 33 imported wood pellets satisfied the NIFOS and ISO standards. The results did not change even with the Grade 4 of NIFOS ( $\leqq 0.05 \%$ ) or B Grade by ISO ( $\leqq$ $0.05 \%$ ). The current wood pellet safety evaluation standards define the allowable sulfur content as $0.05 \%$ or lower, which needs to be revised.

\subsection{Chlorine}

The combustion of organic compounds containing chlorine produces a compound called dioxin. Under unstable combustion at low temperature, more dioxin is produced. Dioxin is a carcinogen, causes problems in the immune system, changes the hormone control functions and is known to cause liver cancer.

Shown in Table 5 are the results of the chlorine content in wood pellets. The chlorine content in

Table 4. Number of companies classified by the sulfur content of wood pellets

\begin{tabular}{|c|c|c|c|c|c|c|c|c|}
\hline (Unit: \%) & $\leqq 0.01$ & $\leqq 0.02$ & $\leqq 0.03$ & $\leqq 0.04$ & $\leqq 0.05$ & $\leqq 0.06$ & $\leqq 0.07$ & $>0.1$ \\
\hline Domestic & 16 & 2 & & & & & & \\
\hline Imported & 14 & 6 & 5 & 5 & & & 1 & 2 \\
\hline
\end{tabular}

* Maximum S content for 1st-grade wood pellets standard designated by NIFOS was $\leqq 0.05 \%$.

* Maximum S content for A1-grade wood pellets standard designated by ISO was $\leqq 0.04 \%$.

Table 5. Number of companies classified by the chlorine content of wood pellets

\begin{tabular}{|c|c|c|c|c|c|c|c|c|}
\hline (Unit: \%) & $\leqq 0.01$ & $\leqq 0.02$ & $\leqq 0.03$ & $\leqq 0.04$ & $\leqq 0.05$ & $\leqq 0.06$ & $\leqq 0.07$ & $>0.1$ \\
\hline Domestic & 17 & 1 & & & & & & \\
\hline Imported & 22 & 4 & 1 & & 2 & & 2 & 2 \\
\hline
\end{tabular}

* Maximum $\mathrm{Cl}$ content for 1st-grade wood pellets standard designated by NIFOS was $\leqq 0.05 \%$.

* Maximum $\mathrm{Cl}$ content for A1-grade wood pellets standard designated by ISO was $\leqq 0.02 \%$. 
domestic wood pellets was below the Grade 1 of NIFOS ( $\leqq 0.05 \%)$ and the non- industrial wood pellet Grade A1 ( $\leqq 0.02 \%)$ by ISO. However, the chlorine content of 29 out of 33 imported wood pellets satisfied the Grade 1 by NIFOS and only 26 imported wood pellets satisfied Grade A1 by ISO. When the ISO Grade B ( $\leqq 0.03 \%$ ) was applied, 27 imported wood pellets satisfied the standards.

Currently, the Wood Pellet Safety Evaluation Standards stipulate the allowable chlorine content to be $0.05 \%$ or lower. But the chlorine content in ISO non-industrial Grade B wood pellets is $0.03 \%$ or below, and Grade I3 is $0.1 \%$ or below. Therefore, new discussion on the chlorine tolerance of Wood Pellet Safety Evaluation Standards is needed. Particularly, the chlorine content of domestic wood pellets is very low, but that of some imported wood pellets is still high so that there need safety measurement plans would be required.

\subsection{Heavy metal}

Once in the body, heavy metal cannot be easily discharged, and cause serious problems as it is stored within the protein and causes side effects in the long term (Biedermann \& Obernberger, 2005). If introduced in the body, mercury can be combined with hemoglobin, and hemoglobin loses the function of delivering oxygen. Lead paralyzes nerves and muscles, and cadmium can cause lung cancer and softens bones.
Table 6 and Table 7 show the measurements of heavy metal in wood pellets. In all heavy metal content measured, the domestic wood pellets showed very low content level way below the Grade 1 of NIFOS and the non-industrial wood pellet Grade A1 by ISO. In the case of the imported wood pellets, they satisfied the standards on copper, nickel, and zinc, but their cadmium, chrome, mercury, lead, arsenic content exceeded the standards.

Arsenic was not detected in any of the domestic products and any of the imported wood pellets, except one, which had $20 \mathrm{mg} / \mathrm{kg}$ of arsenic. Cadmium in all domestic products was below the Grade 1 by NIFOS ( $\leqq 0.5 \mathrm{mg} / \mathrm{kg}$ ) and non- industrial wood pellet Grade A1 by ISO ( $\leqq 0.5 \mathrm{mg} / \mathrm{kg}$ ). All imported wood pellets satisfied the standards, except one. Mercury was not detected in any of the domestic and imported goods except one, which had $10 \mathrm{mg} / \mathrm{kg}$.

Meanwhile, the chrome, copper, lead, nickel and zinc content by pellet item showed that the copper, nickel and zinc content was very low in all domestic and imported wood pellets and satisfied the domestic and ISO standards. The chrome and lead content were very low in all domestic wood pellets and satisfied the domestic and ISO standards. While most of the imported wood pellets satisfied the standards, one item contained considerable amount of chrome and lead. Therefore, strict adjustment of the wood pellet safety standards for chromium, copper, lead, nickel, and zinc is considered possible.

Table 6. Comparison of heavy metals contents in domestic and imported pellets

\begin{tabular}{ccccccccc}
\hline (Unit: $\mathrm{mg} / \mathrm{kg})$ & $\mathrm{As}$ & $\mathrm{Cd}$ & $\mathrm{Cr}$ & $\mathrm{Cu}$ & $\mathrm{Pb}$ & $\mathrm{Hg}$ & $\mathrm{Ni}$ & $\mathrm{Zn}$ \\
\hline \hline Domestic & 0 & $0 \sim 0.3$ & $1 \sim 2$ & $0.4 \sim 7$ & $0 \sim 2$ & 0 & $0.01 \sim 1$ & $5 \sim 10$ \\
Imported & $0 \sim 20$ & $0 \sim 2$ & $0 \sim 117$ & $0 \sim 7$ & $0 \sim 84.4$ & $0 \sim 10$ & $0 \sim 2$ & $1 \sim 53$ \\
NIFOS 1st-grade & $\leqq 1.0$ & $\leqq 0.5$ & $\leqq 10$ & $\leqq 10$ & $\leqq 10$ & $\leqq 0.05$ & $\leqq 10$ & $\leqq 100$ \\
ISO A1 grade & $\leqq 1.0$ & $\leqq 0.5$ & $\leqq 10$ & $\leqq 10$ & $\leqq 10$ & $\leqq 0.1$ & $\leqq 10$ & $\leqq 100$ \\
\hline
\end{tabular}


Table 7. Number of companies classified by the contents of heavy metals included in their pellets

\begin{tabular}{|c|c|c|c|c|c|c|c|c|}
\hline As $(\mathrm{mg} / \mathrm{kg} \mathrm{dr}$ & & & & & & & & \\
\hline & N.D & $\leqq 0.1$ & $\leqq 0.2$ & $\leqq 0.3$ & $\leqq 0.4$ & $\leqq 0.5$ & $\leqq 1.0$ & $\leqq 20$ \\
\hline Domestic & 6 & & & & & & & \\
\hline Imported & 13 & & & & & & & 1 \\
\hline \multicolumn{9}{|c|}{ Cd (mg/kg dry) } \\
\hline & N.D & $\leqq 0.1$ & $\leqq 0.2$ & $\leqq 0.3$ & $\leqq 0.4$ & $\leqq 0.5$ & $\leqq 1.0$ & $\leqq 2.0$ \\
\hline Domestic & 1 & 1 & 2 & 1 & & & & \\
\hline Imported & 10 & 5 & 1 & 1 & 1 & & & 1 \\
\hline \multicolumn{9}{|c|}{ Cr (mg/kg dry) } \\
\hline & N.D & $\leqq 1$ & $\leqq 2$ & $\leqq 3$ & $\leqq 4$ & $\leqq 5$ & $\leqq 10$ & $\leqq 120$ \\
\hline Domestic & & 4 & 2 & & & & & \\
\hline Imported & 8 & 7 & 1 & 1 & & & & 1 \\
\hline \multicolumn{9}{|c|}{$\mathrm{Cu}$ (mg/kg dry) } \\
\hline & N.D & $\leqq 1$ & $\leqq 2$ & $\leqq 3$ & $\leqq 4$ & $\leqq 5$ & $\leqq 7$ & $\leqq 10$ \\
\hline Domestic & & 3 & 2 & & & & 1 & \\
\hline Imported & 1 & & 2 & 3 & 1 & 1 & 3 & \\
\hline \multicolumn{9}{|c|}{$\mathrm{Pb}$ (mg/kg dry) } \\
\hline & N.D & $\leqq 1$ & $\leqq 2$ & $\leqq 3$ & $\leqq 4$ & $\leqq 5$ & $\leqq 10$ & $\leqq 100$ \\
\hline Domestic & 1 & & 5 & & & & & \\
\hline Imported & 3 & 3 & 2 & 1 & 4 & 1 & & 4 \\
\hline \multicolumn{9}{|c|}{$\mathrm{Hg}$ (mg/kg dry) } \\
\hline & N.D & $\leqq 0.01$ & $\leqq 0.03$ & $\leqq 0.05$ & $\leqq 0.1$ & $\leqq 0.5$ & $\leqq 1.0$ & $\leqq 10$ \\
\hline Domestic & 6 & & & & & & & \\
\hline Imported & 17 & & & & & & & 1 \\
\hline \multicolumn{9}{|c|}{ Ni (mg/kg dry) } \\
\hline & N.D & $\leqq 0.01$ & $\leqq 0.1$ & $\leqq 0.3$ & $\leqq 0.6$ & $\leqq 1$ & $\leqq 3$ & $\leqq 10$ \\
\hline Domestic & & 1 & & & 2 & 3 & & \\
\hline Imported & 2 & & & 2 & 1 & 6 & 1 & \\
\hline \multicolumn{9}{|c|}{ Zn (mg/kg dry) } \\
\hline & N.D & $\leqq 1$ & $\leqq 3$ & $\leqq 5$ & $\leqq 7$ & $\leqq 10$ & $\leqq 16$ & $\leqq 100$ \\
\hline Domestic & & & & 1 & 3 & 2 & & \\
\hline Imported & & 1 & 2 & 2 & 2 & 1 & 4 & 1 \\
\hline
\end{tabular}

\subsection{Radioactivity}

Particles or electromagnetic waves that are emitted as radioactive materials are decomposed cause chemical deformation of the DNA, resulting in cancer, birth of deformed children, anaemia, or leukaemia as well as the damage on the immune system (Do, 2011).
Currently, the allowable radioactivity exposure limit per year is $1 \mathrm{mSv}$. During the $\mathrm{X}$-ray filming, the radioactivity level is between 0.03 and $0.05 \mathrm{mSv}$; the exposure at between 1,000 and 2,000 mSv causes vomiting and nausea, and the exposure over 30,000 $\mathrm{mSv}$ results in seizure and convulsion and can lead to death. 
Table 8. Concentration of radioactivity released from domestic-circulated wood pellets

\begin{tabular}{ccc}
\hline Type of wood pellet & Cs-134 $(\mathrm{Bq} / \mathrm{kg})$ & Cs-137 $(\mathrm{Bq} / \mathrm{kg})$ \\
\hline \hline A (domestic) & $<0.10$ & $<0.13$ \\
B (domestic) & $<0.11$ & $<0.11$ \\
C (domestic) & $<0.12$ & $<0.17$ \\
D (Imported) & $<0.17$ & $17.1(1.8)^{1}$ \\
\hline
\end{tabular}

* < means less than the minimum requirement of detection for Cs-134 and Cs-137.

${ }^{1}$ Number in parenthesis is the standard deviation of measured values.

In June 2009, Italy ordered a recall of 10,000 tons of wood pellets imported from Lithuania (Nuclear Power Daily, 2009) because 300Bq/kg of radioactive cesium (Cs-137) from wood pellets and 40,000Bq/kg from fly ash were detected. It was reported that this was due to the Chernobyl nuclear accident that had occurred in April 1986 then in the Soviet Union.

Japan Forestry Agency measured the radioactive cesium content in March 2012 after the Fukushima Nuclear Plant Accident, which showed that the radioactive cesium content in wood pellets sampled nationwide was $1-78 \mathrm{~Bq} / \mathrm{kg}$, and the radioactive cesium content in pellet fly ash was $770-7,400 \mathrm{~Bq} / \mathrm{kg}$ (Japan Forestry Agency, 2012). Also, a considerable amount of radioactive cesium was detected in the fly ash of wood pellets produced with European wood sawdust and subsequently, these wood pellets were recalled. In that case, it was believed that this was due to the Chernobyl nuclear accident.

On the other hand, a survey on the quality and distribution structure of wood pellets produced and distributed in the Korean market, conducted by Korea Forest Service in 2012, showed that some imported pellets from Japan showed cesium radioactivity (Han, 2012). Accordingly, Korea Forest Service announced the Radioactivity Preliminary Safety Standards in December 2012, where they prohibited the distribution of wood pellets which had radioactivity content over $40 \mathrm{~Bq} / \mathrm{kg}$ and wood pellets of which fly ash had over $4,000 \mathrm{~Bq} / \mathrm{kg}$ of radioactivity (KFS, 2012). Meanwhile, they announced that caution would be required for wood pellets with radioactivity content over $4 \mathrm{~Bq} / \mathrm{kg}$ and for processing fly ash which had over $400 \mathrm{~Bq} / \mathrm{kg}$ of radioactivity.

Shown in Table 8 are the results of radioactivity content in wood pellets distributed domestically. The radioactivity content in domestic wood pellets was shown to be below the minimal allowable detection limit whereas radioactive cesium was detected on those imported from Japan. Therefore, there is potential radioactive contamination with imported wood pellets depending on the origin, and the need for establishing the safety evaluation standards for artificial radioactive materials like cesium was raised (Han, 2013). Accordingly, in 2014, NIFOS provided the Wood Product Safety Evaluation Standards, and currently, the allowable amount of cesium radioactivity in wood pellets is defined to be below 30Bq/kg (NIFOS, 2017).

\section{CONCLUSION}

The present study is a preliminary survey for the establishment of the Wood Pellet Safety Evaluation Standards and analyzed the characteristics of wood pellets distributed domestically from July to November 2013. It examined the nitrogen, sulfur, chlorine, heavy metal and cesium radioactivity content in wood pellets as potential materials hazardous in human bodies and environments.

The sulfur, nitrogen, chlorine, and heavy metal 
content in domestic wood pellets satisfied both the Grade 1 standards by NIFOS and non-industrial wood pellet Grade A1 by ISO. However, a number of imported wood pellets either exceeded the Grade 4 of NIFOS or Grade I3 by ISO in terms of the nitrogen, sulfur, chlorine, and heavy metal content. In terms of the wood pellet safety evaluation standards, the nitrogen content would need stricter standards, and in case of the sulfur and chlorine content, some revisions would be required.

While cesium radioactivity was not detected in domestic wood pellets, it was detected in imported wood pellets, which was below the allowable amount of cesium radioactivity stipulated in the Wood Pellet Safety Evaluation Standards at 30Bq $/ \mathrm{kg}$. In the Wood Pellet Safety Evaluation Standards, determining the allowable amount of cesium radioactivity content would contribute to the radioactive-safe use of wood pellets.

\section{REFERENCES}

Biedermann, F., Obernberger, I. 2005. Ash-related problems during biomass combustion and possibilities for sustainable ash utilisation. http://www.biosbioenergy.at/uploads/media/Paper-Biedermann-As hRelated-2005-10-11.pdf.

Do, K.H. 2011. The health effects of low-dose radiation exposure. Journal of the Korean Medical Association 54(12): 1253-1261.

European Biomass Association, 2013. First International Workshop on Pellet Safety. AEBIOM, Brussels, Belgium.

Forest Biomass Energy Association. 2017. Status of wood pellets imported from abroad. http://www. biomassenergy.kr/, Cheongju, Korea.

International Organization for Standardization. 2014. Solid biofuels - Fuel specification and classes. Part 2: Graded wood pellets. ISO 17225-2. Brussel, Belgium.

Han, G.-S. 2012. Survey on Quality and Marketing
System of Wood Pellet. Korea Forest Service, Daejeon, Korea.

Han, G.-S. 2013. Establishment of Standard and Methods for Evaluating the Safety of Wood Pellets. Korea Forestry Promotion Institute, Seoul, Korea Japan Forestry Agency. 2012. Investigation of the Concentration of Radioactive Cesium in Woody Pellets and Stove Burned Ash. http://www.rinya. maff.go.jp/j/press/riyou/120327.html

Kang, D.R., Han, G.-S., Lee, S.M., Lee, O.K., Cho, S.T. 2010. Quality analysis of some domestic wood pellets. Proceedings of the Korean Society of Wood Science and Technology Annual Meeting, pp.83-84. Kim., S.H., Jeong, S.G., No, S.G., Kim, M.Y., Han, G.-S. 2013. Comparison of quality of wood pellets distributed in Korea. Proceedings of the Korean Society of Wood Science and Technology Annual Meeting, pp.118-119.

Kim, S.H., Yang, I., Han, G.-S. 2015. Effect of sawdust moisture content and particle size on the fuel characteristics of wood pellet fabricated with Quercus mongolica, Pinus densiflora and Larix kaempferi Sawdust. Journal of The Korean Wood Science and Technology 43(6): 757-767.

Korea Forest Service. 2012. Preparatory Safety Standards of Radioactivity Released from Wood Pellets. KFS, Daejeon, Korea.

Korea Forest Service. 2017. Safety Evaluation Standard for Wood-based Products. KFS, Daejeon, Korea.

Korea Forest Service. 2018. Act on the Sustainable Use of Wood. KFS, Daejeon, Korea.

Lee, S.M., Choi, D.H., Cho, S.T., Nam, T.H., Han, G.S. Yang, I. 2011. Effect of various factors on the durability of pellets fabricated with Larix kaempferi C. and Liriodendron tulipifera L. sawdus, Journal of the Korean Wood Science and Technology 39(3): 258-268.

Ministry of Environment. 2018. Air Pollution Level. ME, Sejong, Republic of Korea. http://www.me. 
go.kr/mamo/web/index.do?menuId=587.

Nam, T.H., Lee, S.O., Choi, D.H., Han, G.-S. 2011. Quality analysis of some domestic and imported wood pellets. Proceedings of the Korean Society of Wood Science and Technology Annual Meeting, pp.138-139.

National Institute of Forest Science. 2017. Standard and Quality Criteria of Wood-based Products, NIFOS, Seoul, Korea.

Nuclear Power Daily. 2009. Italy Recalls Radioactive
Wood Pellet Fuel: Report. http://www.nuclear powerdaily.com/reports/Italy_recalls_radioactive_ wood_pellet_fuel_report_999.html.

Yang, I., Chae, H.-G., Han, G.-S. 2017. Effect of bark and drying waste liquor of Larix kaempferi used as an additive on the fuel characteristics of wood pellet fabricated with Rigida pine and Quercus mongolica sawdust, Journal of the Korean Wood Science and Technology 45(3): 258-267. 


\title{
APPENDIX
}

\author{
(Korean Version)
}

\section{목재펠릿의 안전성평가 기준 마련을 위한 예비 조사}

요약 : 목재펠릿 사용량이 증가함에 따라 사용하는 사람과 환경에 물리적·화학적 피해가 발생하지 않도록 목재펠릿 자체의 안전성에 대한 관심이 증가하고 있다. 본 연구는 목재펠릿의 안전성평가 기준 제정을 위한 예비조사로서, 국내에서 유통 중인 목재펠릿의 질소, 황, 염소, 비소, 카드뮴, 크롬, 구리, 납, 수은, 니켈, 아연, 세슘방사능의 함유량을 조사하였다. 국내산 목재펠릿 의 질소, 황, 염소 및 중금속 함유량은 국립산림과학원의 목재펠릿 품질 1 급 기준과 ISO의 비산업용 목재펠릿 A1급 기준 및 목재펠릿 안전성 평가기준을 만족하였다. 그러나 수입 목재펠릿의 경우 일부 목재펠릿의 질소, 황, 염소 및 중금속 함유량이 안전성 평가기준의 허용량을 초과하였다. 국내산 목재펠릿에서는 세슘방사능이 검출되지 않았다. 일본으로부터 수입된 목재펠 릿으로부터는 세슘방사능이 검출되었으나, 목재펠릿 안전성평가 기준에 규정된 허용량을 하회하였다. 결론적으로 목재펠릿 안전성 평가기준 설정은 안전한 목재펠릿 이용에 기여할 것으로 판단된다.

\section{1. 서 론}

우리나라에서는 2009년부터 목재펠릿이 생산되기 시작하여, 2017년 연간 30만 톤 규모의 공장이 완공되는 등 그 시장 규모가 계속 증가하고 있다(KEA, 2017). 한편 수입되는 목재펠릿 양도 급속히 증가하여, 2016년 베트남, 말레이시아 등으로부터 약 170만 톤이 수입되었다(FBEA, 2017).

목재펠릿 사용량의 증가와 함께 생산자, 사용자 및 환경에 대한 안전성 문제가 유럽연합을 중심으로 제기되고 있다(AEBIOM, 2013). 2010년 이후 유럽에서 목재펠릿의 사용 및 제조 시 발생된 유독가스, 화재, 폭발 등의 인명피해 사건이 보고되었다. 목재펠릿의 연소 시 발생되는 일산화탄소, 질소 및 황산화물, 탄화수소, 미세먼지, 휘발성 유기화합물, 다환 방향족 탄화수소 등에 의한 인체 및 환경 위해성에 대해서도 논란이 제기되고 있다. 따라서 2013년 3월 오스트리아의 Fugen에서 목재펠릿의 안전성에 과한 국제회의가 처음으로 개최되었으며, 이 회의를 통하여 문제점 및 해결 방안이 논의되었다.

2012년 5월 제정된 “목재의 지속가능한 이용에 관한 법률(KFS, 2018)”에서는 목재제품을 생산판매 또는 이용할 때 사람과 환경에 물리적·화학적 피해가 발생하지 않도록 목재제품의 안전성평가를 할 수 있다고 규정하였다. 이 법률에 근거하여 2014년 12월 “목재제품 안전성평가 기준(KFS, 2017)”이 고시되었다(Table 1 참조). 목재펠릿에 대해서는 세슘방사능, 황, 염소, 질소, 비소, 카드뮴, 크롬, 구리, 납, 수은, 니켈, 아연에 대한 허용량을 설정하여 평가하도록 하고 있다. 국내의 목재펠릿 관련 연구는 주로 제조 특성에 집중되어 있으며(Lee et al., 2011, Kim et al., 2015, Yang et al., 2017), 국내에서 생산 또는 유통되고 있는 목재펠릿에 대한 성분 분석은 몇 차례 보고된 것에 불과하다(Kang et al., 2010, Nam et al., 2011, Kim et al., 2013).

그런데 목재펠릿의 안전성평가 기준 제정을 위해서는 국내에서 생산 및 유통되고 있는 목재펠릿 제품의 품질 현황을 파악하는 것이 필요하다. 한국임업진흥원에서는 “목재제품 안전성평가 기준” 고시를 위한 예비조사로서 2013년 7월부터 2013년 11월까 지 국내에서 유통된 목재펠릿의 특성을 분석하였다. 따라서 본 연구에서는 이들 결과를 이후 고시된 “목재제품 안전성평가 기준”과 “목재펠릿의 규격·품질기준”과 대비하여 분석함으로써 안전성 평가 기준의 수정 방향성을 제안하고자 한다.

\section{2. 재료 및 방법}

\section{1 공시재료}

산림청이 국내에서 2013년 7월부터 2013년 11월 사이에 수거한 국내산 18종과 수입산 33종의 목재펠릿을 공시재료로 사용하였다.

2.2 질소분, 유황분, 염소분, 무기성분 및 방사능 분석

국립산림과학원 고시의 목재펠릿의 규격과 품질기준에 기술된 방법(NIFOS, 2017)에 의거하여 목재펠릿의 질소분, 유황분, 염소분 및 무기성분을 한국임업진흥원에 의뢰하여 조사하였다. 질소는 원소분석기로, 황과 염소는 이온크로마토그래피로, 무기 성분은 유도결합 플라즈마 질량분석기로 분석되었다. 
목재펠릿으로부터 방출되는 방사능은 HASL-300 Ga-01-R(1997) 시험방법의 의거하여 한국원자력연구원의 고순도 게르마 늄 검출기를 장착한 감마선분광기를 이용하여 Cs-134, Cs-137, I-131 핵종의 방사능농도 $(\mathrm{Bq} / \mathrm{kg})$ 를 측정하였다. 측정에 이용한 목재펠릿은 $500 \mathrm{~g}$ 이었으며, 측정시간은 $86,000 \mathrm{sec}$ 였다.

\section{3. 결과 및 고찰}

3.1 질소

질소로부터 발생되는 대표적인 유해물질로는 질소산화물 $\left(\mathrm{NO}_{\mathrm{x}}\right)$ 이 있는데 초미세먼지의 전구물질로도 작용한다고 알려져 있다. 질소산화물은 폐질환, 호흡기질환, 면역기능 약화 등을 유발시키며, 질소산화물에 의한 연간 사망률은 10만 명당 21.8-34.5 명 정도로 추산되고 있다(ME, 2018). 목재펠릿의 질소함유량을 측정한 결과는 Table 2와 같다. 국내산 목재펠릿의 질소함유량은 모두 국립산림과학원 품질규격 1 급 $(\leqq 0.3 \%)$ 기준과 $\mathrm{ISO}$ 의 비산업용 목재펠릿 품질규격 $\mathrm{A} 1$ 급 $(\leqq 0.3 \%)$ 기준 이하인 것으로 조사되었다(NIFOS, 2017; ISO, 2014). 그러나 수입 목재펠릿의 질소함유량은 전체 35개 품목 가운데 20개 품목만 국립산림과학 원 1급 및 ISO 비산업용 A1급 기준을 만족하였다. 국립산림과학원 4급( $\leqq 1.0 \%)$ 및 ISO 비산업용 B급 $(\leqq 1.0 \%)$ 기준을 적용하면, 3 개 품목을 제외한 거의 대부분의 목재펠릿이 질소함유량 품질 기준에 적합하였다.

목재펠릿 안전성평가 기준에는 질소 허용량이 $1.0 \%$ 이하로 규정되어 있다. 그런데 ISO의 산업용 목재펠릿 I3급 질소 함유량 기준은 $0.6 \%$ 이하로 규정되어 있다. 우리나라는 발전용 목재펠릿의 사용량이 전체의 $95 \%$ 정도를 차지하고 있다. 따라서 목재펠 릿 안전성평가 기준의 질소 허용량을 줄여야 할 필요가 있다.

\section{2 황}

황산화물 $\left(\mathrm{SO}_{\mathrm{x}}\right)$ 은 산소와 황이 화합한 물질의 총칭으로 황을 함유한 화석 연료가 연소되면서 주로 발생한다. 황산화물도 초미세먼지의 전구물질로 작용하는데, 기관지염, 호흡기 질환 및 천식을 유발시켜 연간 10만 명당 16.6-26.1명을 사망에 이르게 한다고 알려져 있다(ME, 2018). 목재펠릿의 황 함유량을 측정하였으며, 이 결과를 Table 4에 나타내었다. 국내산 목재펠릿의 황 함유량은 전 품목에서 국립산림과학원 품질규격 1 급 $(\leqq 0.05 \%)$ 기준과 ISO의 비산업용 목재펠릿 품질규격 $\mathrm{A} 1$ 급 $\leqq 0.04 \%)$ 기준 이하인 것으로 조사되었다. 그러나 수입 목재펠릿의 황 함유량은 전체 33개 품목 가운데 30 개 품목이 국립산림과학원 1 급 및 ISO A1급 기준을 만족하였다. 국립산림과학원 4 급 $(\leqq 0.05 \%)$ 및 ISO B급 $(\leqq 0.05 \%)$ 기준을 적용하더라도 변함이 없다. 현재의 목재펠릿 안전성평가 기준에 황 허용량이 $0.05 \%$ 이하로 규정되어 있는데, 이에 대한 조정이 필요하다.

\section{3 염소}

염소를 함유하고 있는 유기화합물이 연소될 때 다이옥신이라는 화합물이 생성된다. 낮은 온도에서 불완전 연소가 일어나면 더 많은 다이옥신을 방출하게 된다. 다이옥신은 발암물질로 분류되고 있으며, 면역 체계에 이상을 가져오기도 하고 호르몬 조절기능에 변화를 주어 간암 등을 유발한다고 알려져 있다. 목재펠릿의 염소 함유량을 조사한 결과는 Table 5 과 같다. 국내산 목재펠릿의 염소 함유량은 전 품목에서 국립산림과학원 품질규격 1 급( $\leqq 0.05 \%)$ 기준과 $\mathrm{ISO}$ 의 비산업용 목재펠릿 품질규격 $\mathrm{A} 1$ 급 $(\leqq 0.02 \%)$ 기준 이하인 것으로 조사되었다. 그러나 수입 목재펠릿의 염소 함유량은 전체 33 개 품목 가운데 29개 품목이 국립산림과학원 1 급 기준에 그리고 26개 품목이 ISO A1 기준을 만족하였다. ISO B급( $\leqq 0.03 \%)$ 기준을 적용하면 27개 품목이 기준을 만족하였다. 현재 목재펠릿 안전성평가 기준에는 염소 허용량이 $0.05 \%$ 이하로 규정되어 있다. 그런데 ISO의 비산업용 $\mathrm{B}$ 급 목재펠릿의 염소 함유량은 $0.03 \%$ 이하, I3급 염소 함유량은 $0.1 \%$ 이하로 규정되어 있다. 따라서 목재펠릿 안전성평가 기준의 염소 허용량에 대한 새로운 논의가 필요하다. 특히 국내산 목재펠릿의 염소 함유량은 매우 낮은 편이나, 일부 수입 목재펠릿은 염소 함유량이 높아 이에 대한 안전성 확보 방안이 필요할 것으로 생각한다.

\section{4 중금속}

중금속은 체내에 들어오면 잘 배설되지 않고 우리 몸속의 단백질에 쌓여 장기간에 걸쳐 부작용을 나타내기 때문에 매우 위험하다(Biedermann \& Obernberger, 2005). 우리 몸속에 수은이 들어와 헤모글로빈과 결합하면 산소운반능력을 상실하게 된다. 납은 신경과 근육을 마비시키고, 카드뮴은 폐암을 일으킬 수 있으며 뼈를 무르게 한다.

목재펠릿의 중금속 함유량을 측정한 결과는 Table 6 및 Table 7와 같다. 국내산 목재펠릿의 경우 조사된 모든 중금속 항목에서 국립산림과학원의 목재펠릿 품질 1급 기준과 ISO의 비산업용 목재펠릿 A1급보다 크게 낮은 것으로 조사되었다. 수입 목재펠릿 의 경우, 구리, 니켈, 아연 함유량은 각 기준을 만족하였으나, 카드뮴, 크롬, 수은, 납, 비소 함유량은 기준을 상회하였다. 
비소는 국내산 전 품목과 한 품목을 제외한 수입 목재펠릿에서는 검출되지 않았으나, 한 품목의 수입제품에서 $20 \mathrm{mg} / \mathrm{kg}$ 검출되었다. 카드뮴은 국내산 전 품목이 국립산림과학원 품질규격 1 급 기준 $\leqq 0.5 \mathrm{mg} / \mathrm{kg})$ 과 ISO의 비산업용 목재펠릿 품질규격 $\mathrm{A} 1$ 급 기준 $\leqq 0.5 \mathrm{mg} / \mathrm{kg})$ 이하로 조사되었다. 수입 목재펠릿에서도 한 품목을 제외하고 국내 및 ISO 기준을 만족하였다. 수은은 국내산 전 품목과 한 품목을 제외한 수입 목재펠릿에서는 검출되지 않았으나, 한 품목의 수입제품에서 $10 \mathrm{mg} / \mathrm{kg}$ 검출되었다.

한편 크롬, 구리, 납, 니켈 그리고 아연의 목재펠릿 함유량을 펠릿 품목별로 조사한 결과, 구리, 니켈, 아연은 국내산 및 수입 펠릿 전 품목에서 매우 낮은 함유량을 나타내며 국내 및 ISO 기준을 만족하였다. 크롬과 납 함유량도 국내산의 경우 전 품목 매우 낮은 값으로 국내 및 ISO 기준을 만족하였다. 수입 목재펠릿의 경우도 거의 대부분 국내산 목재펠릿과 유사하게 기준을 만족하였으나, 한 품목에서 매우 많은 크롬과 납을 함유하고 있었다. 따라서 크롬, 구리, 납, 니켈, 아연에 대한 목재펠릿 안전성 기준 항목 기준치의 상향 조정도 가능할 것으로 판단된다.

\section{4 방사능}

방사능 물질이 분해되면서 방출하는 입자나 전자기파는 DNA의 화학적 변성을 초래하여 암, 기형아 출산, 빈혈, 백혈병 등 유발시킬 수 있으며, 면역기능 손상 등을 일으키는 것으로 보고되고 있다(Do, 2011). 현재 연간 방사능 피폭한도는 $1 \mathrm{mSv}$ 로써 $\mathrm{X}$ 선 촬영시 $0.03-0.05 \mathrm{mSv}$, 구토와 메스꺼움의 발생은 $1,000-2,000 \mathrm{mSv}$, 발작과 경련은 3 만 $\mathrm{mSv}$ 이상에서 발생하며 이 경우 사망에까지 이르게 된다.

2009년 6월 이탈리아에서 리투아니아로부터 수입된 10,000 톤의 목재펠릿에 대하여 리콜을 결정하였다(Nuclear Power Daily, 2009). 목재펠릿에서 $300 \mathrm{~Bq} / \mathrm{kg}$ 의 방사성 세슘(Cs-137)이, 연소재에서 $40,000 \mathrm{~Bq} / \mathrm{kg}$ 검출되었기 때문인데, 1986년 4월 구소련의 체르노빌 원자력발전소에서 발생한 사고의 영향인 것으로 보고되었다.

일본의 임야청은 후쿠시마 원자력발전소 방사능 누출사고 이후 2012년 3월 실시한 방사성세슘 농도를 측정한 결과, 전국 각지에서 채취한 목재펠릿의 방사성 세슘 농도는 $1-78 \mathrm{~Bq} / \mathrm{kg}$, 펠릿연소재의 방사성 세슘 농도는 770-7,400 Bq/kg 범위임을 밝혔다(Japan Forestry Agency, 2012). 또한 유럽산 목재의 톱밥으로 제조한 목재펠릿의 연소재에서도 다량의 방사성세슘이 검출되어 리콜되는 사태가 벌어졌다. 이 경우도 체르노빌 원자력발전소에서 발생한 사고의 영향인 것으로 알려졌다.

한편 2012년 산림청에서는 국내에서 생산 및 유통되고 있는 목재펠릿의 품질 및 유통구조 조사 결과 일본으로부터의 일부 수입품에서 세슘방사능이 검출되고 있음을 파악하였다(Han, 2012). 이에 따라 2012년 12월 산림청에서 방사능 예비 안전기준을 고시하였는데, $40 \mathrm{~Bq} / \mathrm{kg}$ 이상의 방사능 농도를 보유한 목재펠릿과 연소재에서 $4,000 \mathrm{~Bq} / \mathrm{kg}$ 이상의 방사능이 검출된 목재펠릿은 유통을 금지하였다(KFS, 2012), 한편 $4 \mathrm{~Bq} / \mathrm{kg}$ 이상의 방사능 농도를 나타낸 목재펠릿과 연소재에서 $400 \mathrm{~Bq} / \mathrm{kg}$ 이상의 방사능이 검출된 목재펠릿의 경우 연소재 처리시 주의가 필요하다고 고시하였다.

Table 8은 국내에서 유통되고 있는 목재펠릿의 방사능 농도를 조사한 결과이다. 국내산 목재펠릿에서의 방사능 농도는 모두 최소 검출한계치 이하로 조사되었으며, 일본에서 수입된 것으로부터 방사성 세슘이 검출되었다. 따라서 수입 목재펠릿에 대해서는 원산지에 따라 방사능 오염의 가능성이 있으므로 세슘과 같은 인공방사능에 대한 안전성평가 기준 마련의 필요성이 제기되었다(Han, 2013). 이에 따라 2014년 국립산림과학원에 의한 목재제품 안전성평가 기준이 마련되었으며, 현재는 목재펠릿 의 세슘방사능 허용량을 $30 \mathrm{~Bq} / \mathrm{kg}$ 이하로 규정하고 있다(NIFOS, 2017).

\section{4. 결 론}

본 연구에서는 그런데 목재펠릿의 안전성평가 기준 제정을 위한 예비조사로서 2013년 7월부터 2013년 11월까지 국내에서 유통된 목재펠릿의 특성을 분석하였다. 인체 및 환경에 대한 유해 가능물질로서 목재펠릿에 함유된 성분 중 질소, 황, 염소, 중금속 및 세슘방사능의 함유량을 조사하였다.

국내산 목재펠릿의 황, 질소, 염소 및 중금속 함유량은 국립산림과학원의 목재펠릿 품질 1급 기준과 ISO의 비산업용 목재펠릿 $\mathrm{A} 1$ 급 기준을 만족하였다. 그러나 수입 목재펠릿의 경우 다수의 목재펠릿의 질소, 황, 염소 및 중금속 함유량이 국립산림과학원의 목재펠릿 품질 4급 기준을 초과하거나 ISO의 산업용 목재펠릿 I3급 기준을 초과하였다. 목재펠릿 안전성 평가기준에 있어서 질소 성분의 경우 현재보다 더 엄격한 기준 설정이 필요하며, 황과 염소 성분의 경우에도 다소 조정이 필요할 것으로 판단된다.

국내산 목재펠릿에서는 세슘방사능이 검출되지 않았으나, 수입 목재펠릿으로부터는 방사성 세슘이 검출되었다. 다만 목재펠 릿 안전성평가 기준에 규정된 세슘방사능 허용량인 $30 \mathrm{~Bq} / \mathrm{kg}$ 을 하회하였다. 목재펠릿 안전성 평가기준에 있어서 세슘방사능 농도의 허용량 설정이 방사능에 안전한 목재펠릿 이용에 기여하는 것으로 판단된다. 